\title{
ANALISIS CITRA CITRA MEREK DAN PROMOSI PENJUALAN TERHADAP LOYALITAS PELANGGAN PT. QUANTUM ICT DI MEDAN
}

\author{
Azizah Hanum, SE,MM \\ Universitas Amir Hamzah \\ azizahhanum484@gmail.com
}

\begin{abstract}
Abstrak
Perkembangan dunia usaha yang dinamis dan penuh persaingan menuntut perusahaan untuk melakukan perubahan orientasi terhadap cara mereka mengeluarkan produk, mempertahankan produknya, menarik konsumen, dan menangani pesaing. Salah satu hal penting yang perlu dilakukan dan diperhatikan oleh setiap perusahaan adalah menarik pelanggan dan dapat mempertahankan pelanggan tersebut agar tetap loyal terhadap perusahaan. Berdasarkan pembahasan keseluruhan penelitian ini, peneliti menarik kesimpulan penelitian secara parsial, citra merek berpengaruh terhadap loyalitas pelanggan pada PT. Quantum ICT karena thitung $>t_{\text {tabel }}$ $(2,288>1,976)$ serta nilai probabilitas sebesar $0,024<0,05$. Promosi penjualan berpengaruh terhadap loyalitas pelanggan pada PT. Quantum ICT karena $t_{\text {hitung }}>\mathrm{t}_{\text {tabel }}(8,869>1,976)$. Secara simultan, citra merek berpengaruh terhadap loyalitas pelanggan pada PT. Quantum ICT karena $F_{\text {hitung }}>F_{\text {tabel }}$ $(40,507>3,06)$ serta nilai probabilitas sebesar $0,000<0,05$. Besarnya pengaruh adalah $35,1 \%$ sedangkan sisanya sebesar $64,9 \%$ diterangkan oleh faktor-faktor lain diluar penelitian ini.
\end{abstract}

Keyword : Citra Merek, Promosi Penjualan, Loyalitas Pelanggan.

\section{PENDAHULUAN}

PT. Quantum ICT merupakan perusahaan distributor sebagai penyedia sistem CCTV, anti petir, tower, dan radio network. Perusahaan sudah berdiri sejak bulan Oktober 2014 Luas cakupan usaha perusahaan bukan hanya terbatas pada wilayah kota Medan saja, tetapi juga meliputi beberapa wilayah di luar kota Medan. Perusahaan ini beralamat di Jalan Kol Yosudarso KM 6.5 Komp. Brayan Prima Blok B No. 3A. Pelanggan perusahaan merupakan toko pengecer dan juga pemakai langsung. Adapun permasalahan yang tengah dihadapi perusahaan saat ini adalah menurunnya jumlah pelanggan perusahaan terutama pada beberapa bulan terakhir ini. Fenomena yang terjadi ini diduga menunjukkan bahwa loyalitas 
pelanggan mengalami penurunan. Merek juga dapat membantu perusahaan untuk memperluas lini produk serta mengembangkan posisi pasar yang spesifik bagi suatu produk. Konsumen yang terbiasa menggunakan merek tertentu cenderung memiliki konsistensi terhadap citra merek (brand image). Citra merek itu sendiri memiliki arti kepada suatu pencitraan sebuah produk dibenak konsumen secara massal. Setiap orang akan memiliki pencitraan yang sama terhadap sebuah merek. Semakin kuat citra merek di benak pelanggan maka semakin kuat pula rasa percaya diri pelanggan untuk tetap loyal atau setia, terhadap produk yang dibelinya sehingga hal tersebut dapat mengantar sebuah perusahaan untuk tetap mendapatkan keuntungan dari waktu ke waktu.

Promosi penjualan (sales promotion) merupakan usaha penjualan khusus dikarenakan promosi penjualan merupakan kegiatan promosi untuk menggugah atau menstimulasi pembelian. Promosi penjualan sering digunakan sebagai alat bantu yang integral bersama-sama advertensi (periklanan) dan personal selling. Dengan demikian, promosi penjualan dapat pula dinyatakan sebagai kegiatan yang melengkapi dan mendorong periklanan dan personal selling. Promosi penjualan juga dapat dipandang sebagai jembatan antara periklanan dan penjualan pribadi karena pada dasarnya itu terdiri dari semua bentuk aktivitas pemasaran.

\section{KAJIAN PUSTAKA}

Citra merek merupakan serangkaian sifat tangible dan intangible, seperti ide, keyakinan, nilai-nilai, kepentingan, dan fitur yang membuatnya menjadi unik.

Promosi penjualan dapat dipandang sebagai jembatan antara periklanan dan penjualan pribadi karena pada dasarnya itu terdiri dari semua bentuk aktivitas pemasaran

Loyalitas pelanggan merupakan perilaku yang terkait dengan merek sebuah produk, termasuk kemungkinan memperbaharui kontrak merek di masa yang akan datang, berapa kemungkinan keinginan pelanggan untuk meningkatkan citra positif suatu produk.

\section{METODE PENELITIAN}

\section{Lokasi Penelitian}

Penelitian dilakukan di PT. Quantum ICT yang beralamat di Jalan Kol Yosudarso KM 6.5 Komp. Brayan Prima Blok B No. 3A. Waktu penelitian dimulai dari bulan Januari 2021 dan selesai pada bulan Juni 2021. 


\section{Populasi dan Sampel}

Populasi dalam penelitian ini adalah konsumen (toko-toko dan konsumen akhir) yang melakukan transaksi pembelian pada bulan Maret dan April 2021 sebanyak 250 konsumen. Untuk menentukan besarnya sampel, peneliti menggunakan rumus Slovin dengan kalkulasi sebagai berikut:

$$
\begin{aligned}
& n=\frac{N}{1+N e^{2}} \\
& =\frac{250}{1+250 \times 0.05^{2}} \\
& =\frac{250}{1+0.625} \\
& =153
\end{aligned}
$$

\section{Teknik Analisis Data}

\section{Analisi Regresi Linear berganda}

Model análisis data yang digunakan dalam penelitian kali ini adalah model análisis Regresi berganda. Peneliti menggunakan Regresi linear berganda karena model ini berguna untuk mencari pengaruh antara dua atau lebih variabel bebas terhadap variabel terikat yang ada. Model persamaan regresi berganda adalah :

$$
\mathrm{Y}=\mathrm{a}+\mathrm{b} 1 \mathrm{X} 1+\mathrm{b} 2 \mathrm{X} 2+\mathrm{e}
$$

Keterangan :

$\mathrm{Y} \quad=$ variabel loyalitas pelanggan

a $\quad=$ konstanta

$\mathrm{b} 1, \mathrm{~b} 2$ = koefisien regresi

$\mathrm{X} 1=$ variabel citra merek

$\mathrm{X} 2$ = variabel promosi penjualan

$\mathrm{e} \quad=$ Standard error

\section{Koefisien Determinasi $\left(\mathbf{R}^{2}\right)$}

Hasil Penelitian Koefisien Determinasi $\left(\mathrm{R}^{2}\right)$ digunakan untuk mengukur proporsi atau presntasi sumbangan variabel bebas yang dteliti yaitu citra merek $\left(\mathrm{X}_{1}\right)$ dan promosi penjualan $\left(\mathrm{X}_{2}\right)$ terhadap loyalitas pelanggan $(\mathrm{Y})$. Koefisien determinasi berkisar antara 0 sampai dengan 1 . Hal ini apabila $\mathrm{R} 2=0$ menunjukan ketidakmampuan variabel independen dalam mempengaruhi variabel dependen. Bila R2 mendekati 1 menunjukan kemampuan variabel independen dalam mempengaruhi variabel dependen. 


\section{DISCUSSION}

\section{Hasil Penelitian}

\section{Metode Persamaan Regresi Berganda}

Persamaan regresi berganda secara umum adalah:

$$
\begin{gathered}
\mathrm{Y}=2,790+0,134 \mathrm{X} 1+0,490 \mathrm{X} 2 . \\
\text { Tabel } 3 \\
\text { Hasil Uji Regresi }
\end{gathered}
$$

\begin{tabular}{|c|c|c|c|c|c|c|}
\hline \multirow[b]{2}{*}{ Model } & & \multicolumn{2}{|c|}{$\begin{array}{l}\text { Unstandardized } \\
\text { Coefficients }\end{array}$} & \multirow{2}{*}{$\begin{array}{c}\text { Standardized } \\
\text { Coefficients }\end{array}$} & \multirow[b]{2}{*}{ t } & \multirow[b]{2}{*}{ Sig. } \\
\hline & & $B$ & Std. Error & & & \\
\hline \multirow[t]{3}{*}{1} & (Constant) & 2.790 & 1.500 & & 1.860 & .065 \\
\hline & Citra_Merek & .134 & .059 & .151 & 2.288 & .024 \\
\hline & Promosi_Penjualan & .490 & .055 & .586 & 8.869 & .000 \\
\hline
\end{tabular}

Coefficients $^{\mathrm{a}}$

\section{Koefisien Determinasi $\left(\mathbf{R}^{2}\right)$}

Tabel 4

Hasil Nilai Korelasi dan Determinasi

Model Summary

\begin{tabular}{|l|r|r|r|r|}
\hline Model & \multicolumn{1}{|c|}{$\mathrm{R}$} & R Square & $\begin{array}{c}\text { Adjusted } \\
\text { R Square }\end{array}$ & $\begin{array}{r}\text { Std. Error of } \\
\text { the Estimate }\end{array}$ \\
\hline 1 & $.592^{\mathrm{a}}$ & .351 & .342 & 2.24100 \\
\hline
\end{tabular}

a. Predictors: (Constant), Promosi_Penjualan, Citra_

Merek

Pada tabel di atas dapat dilihat bahwa besarnya coeficient of determination (R2) adalah 0,351 atau $35,1 \%$ yang berarti variabel-variabel bebas dapat menerangkan perubahan pada variabel loyalitas pelanggan sebesar $35,1 \%$ sedangkan sisanya sebesar $64,9 \%$ diterangkan oleh faktor-faktor lain diluar penelitian ini.

\section{Pengujian Hipotesis}

\section{Pengujian Hipotesis Secara Simultan Menggunakan Uji F}

Hasil uji signifikansi simultan dapat dilihat tabel berikut :

\begin{tabular}{|c|c|c|c|c|c|c|}
\hline \multicolumn{7}{|c|}{ ANOVAb } \\
\hline Model & & $\begin{array}{l}\text { Sum of } \\
\text { Squares }\end{array}$ & $d f$ & Mean Square & $\mathrm{F}$ & Sig. \\
\hline 1 & Regression & 406.859 & 2 & 203.430 & 40.507 & $.000^{a}$ \\
\hline & Residual & 753.311 & 150 & 5.022 & & \\
\hline & Total & 1160.170 & 152 & & & \\
\hline
\end{tabular}

Tabel 5

Hasil Uji F

a. Predictors: (Constant), Promosi_Penjualan, Citra_Merek

b. Dependent Variable: Loyalitas_Pelanggan

Dari tabel di atas dapat terlihat bahwa nilai F hitung sebesar 40,507 dengan probabilitas 0,000 , karena probabilitasnya jauh lebih kecil dari 0,05, maka model regresi dapat digunakan untuk memprediksi Loyalitas Pelanggan. Hal ini juga dapat dilihat dari $F_{\text {hitung }}>F_{\text {tabel }}(40,507>3,06)$, maka Ho ditolak atau Ha diterima 
yang berarti bahwa ada hubungan positif dan pengaruh signifikan secara simultan (bersama-sama) dari variabel Citra Merek dan Promosi Penjualan terhadap Loyalitas Pelanggan pada PT. Quantum di Medan.

\section{Pengujian Hipotesis secara Parsial Menggunakan Uji t \\ a. Pengaruh $\mathbf{X}_{1}$ terhadap $\mathrm{Y}$}

Oleh karena $t_{\text {hitung }}>t_{\text {tabel }}(2,288>1,976)$ serta nilai probabilitas sebesar $0,024<0,05$, maka Ho ditolak berarti ada hubungan positif dan pengaruh signifikan dari variabel Citra Merek terhadap Loyalitas Pelanggan.

\section{b. Pengaruh $\mathrm{X}_{2}$ terhadap $\mathrm{Y}$}

Oleh karena $t_{\text {hitung }}>t_{\text {tabel }}(8,869>1,976)$ serta nilai probabilitas sebesar $0,000<0,05$, maka Ho ditolak berarti ada hubungan positif dan pengaruh signifikan dari variabel Promosi Penjualan terhadap Loyalitas Pelanggan.

\section{KESIMPULAN}

Berdasarkan pembahasan keseluruhan penelitian ini, peneliti menarik kesimpulan penelitian sebagai berikut:

1. Secara parsial, citra merek berpengaruh terhadap loyalitas pelanggan pada PT. Quantum ICT karena $t_{\text {hitung }}>\mathrm{t}_{\text {tabel }}(2,288>1,976)$ serta nilai probabilitas sebesar $0,024<0,05$.

2. Secara parsial, promosi penjualan berpengaruh terhadap loyalitas pelanggan pada PT. Quantum ICT karena karena thitung $>t_{\text {tabel }}(8,869>1,976)$ serta nilai probabilitas sebesar $0,000<0,05$.

3. Secara simultan, citra merek dan promosi penjualan berpengaruh terhadap loyalitas pelanggan pada PT. Quantum ICT karena $F_{\text {hitung }}>F_{\text {tabel }}(40,507>$ $3,06)$ serta nilai probabilitas sebesar $0,000<0,05$.

4. Besarnya pengaruh citra merek dan promosi penjualan terhadap loyalitas pelanggan pada PT. Quantum ICT adalah sebesar 35,1\% sedangkan sisanya sebesar 64,9\% diterangkan oleh faktor-faktor lain diluar penelitian ini.

\section{REFERENCES}

Ajriya, Aghnia. 2013. Pengaruh Promosi Penjualan Terhadap Loyalitas Pelanggan (Studi Bisnis pada Depot Air Minum Isi Ulang Faqih Water Kelurahan Sei Putih Baru Medan). Medan : Universitas Sumatera Utara. 
Alma, Buchari. 2011. Manajemen Pemasaran dan Pemasaran Jasa. Cetakan Kesembilan. Bandung : Penerbit Alfabeta.

Arikunto, Suharsimi. 2010. Prosedur Penelitian - Suatu Pendekatan Praktik. Jakarta: Rineka Cipta.

Assauri, Sofjan. 2010. Manajemen Pemasaran: Dasar, Konsep, dan Strategi. Jakarta : RajaGrafindo Persada.

Ghozali, Imam. 2013. Aplikasi Analisis Multivariate dengan Program IBM SPSS 21. Cetakan Ketujuh. Semarang : Badan Penerbit Universitas Diponegoro.

Ginting, Nembah F. Hartimbul. 2011. Manajemen Pemasaran. Bandung : Yrama Widya.

Gunawan, Muhammad Ali. 2015. Statistik Penelitian Bidang Pendidikan, Psikologi, dan Sosial: Dilengkapi Dengan Contoh Secara Manual dan SPSS. Yogyakarta : Parama Publishing.

Hasan, Ali. 2013. Marketing dan Kasus-Kasus Pilihan. Cetakan Pertama. Yogyakarta : CAPS.

Manullang, M. 2013. Pengantar Bisnis. Jakarta : PT. Indeks.

Priyatno, Duwi. 2010. Paham Analisa Statistik Data dengan SPSS. Yogyakarta: Penerbit MediaKom.

Priyatno, Duwi. 2014. SPSS 22: Pengolah Data Terpraktis. Yogyakarta: Penerbit Andi.

Rahmayanty, Nina. 2010. Manajemen Pelayanan Prima. Yogyakarta : Graha Ilmu.

Sangadji, Etta Mamang dan Sopiah. 2013. Perilaku Konsumen - Pendekatan Praktis Disertai: Himpunan Jurnal Penelitian. Yogyakarta : Penerbit Andi.

Setiyaningrum, Ari dkk. 2015. Prinsip-prinsip Pemasaran - Plus Tren Terkini tentang Pemasaran Global, Pemasaran Jasa, Green Marketing, Entrepreneural Marketing dan E-Marketing. Yogyakarta : Andi.

Siregar, Syofian. 2014. Metode Penelitian Kuantitatif: Dilengkapi dengan Perbandingan Perhitungan 